\title{
RARE RENAL DISEASE IN MACEDONIA - AN UPDATE
}

\author{
Velibor Tasic $^{1}$, Zoran Gucev $^{1}$, Momir Polenakovic ${ }^{2}$ \\ ${ }^{1}$ University Children's Hospital Medical School, Skopje, Republic of Macedonia \\ ${ }^{2}$ Macedonia Academy of Science and Arts, Skopje, Republic of Macedonia
}

Corresponding author: Momir Polenakovic, Macedonian Academy of Sciences and Arts, Bul. Krste Misirkov 2, Skopje, Republic of Macedonia, email: momir@manu.edu.mk

\begin{abstract}
Rare renal diseases (RRD) are an important category of rare disease (RD) as they can do great damage to the patients, families and society. The patient may undergo years even decades of numerous investigations including invasive procedures and yet not have definitive and precise diagnose and therefore, no opportunity for appropriate treatment. The great progress in molecular genetic techniques characterized many Mendelian diseases on molecular level. This gave the possibility for appropriate prevention and treatment interventions, genetic counseling and prenatal diagnosis. Herein, we summarize the current status of RRD in Macedonia. The research interest of Macedonian clinicians and scientists is focused on the genetics of congenital anomalies of the kidney and urinary tract (CAKUT), steroid resistant nephrotic syndrome, nephrolithiasis and nephrocalcinosis, cystic diseases and cilliopathies with collaborations with eminent laboratories in Unites States and Europe. This collaboration resulted in detection of new genes and pathophysiological pathways published in The New England Journal of Medicine and in other high impact journals. Macedonian health professionals have knowledge and equipment for diagnosis of RRD. Unfortunately the lack of finances is great obstacle for early and appropriate diagnosis. Participation in the international registries, studies and trials should be encouraged. This would result in significant benefit for the patients, health professionals and science.
\end{abstract}

Keywords: rare renal diseases, genetic, Macedonia

\section{INTRODUCTION}

The definition of rare disease varies: it is less than $1 / 2000$ in Europe, 1/1250 in USA, 1/2000 in Japan and $1 / 500,000$ cases in China. It is estimated that 30 million people suffer from rare disease in Europe and 20 million in US [1,2]. The term orphan disease is also used for rare diseases to illustrate the challenges related to their diagnosis, comprehensive and often multidisciplinary man- agement and insufficient and extremely expensive drug therapy which do not attract the pharmaceutical industry for its development and production. The majority of patients have genetic origin of the $\mathrm{RD}$, although some infectious, allergic, malignant, autoimmune and degenerative diseases may meet the criteria for RD. There is an ethnic variation of the RDs, too. The Finish type of the congenital 
nephrotic syndrome is relatively common among Finish population (1/8200). In the South-Eastern Europe, cystinuria is more prevalent among the Roma population and is characterized with typical mutation in the SLC3A1 [3]. Hereditary renal hypouricemia is prevalent in the Japanese population, although cases of this disease have been recently reported in the Caucasian population including patients from Macedonia [4]. Interestingly, cystinosis, which is the most common cause of Fancony syndrome, has not been diagnosed in Macedonia in the last 30 years [5, 6].

Rare renal diseases represent an important category of RDs since they inflict significant burden on the patients, families and society. The patient may undergo years even decades of numerous investigations including invasive procedures and still not have definitive and precise diagnosis and therefore inappropriate treatment. The term diagnostic Odyssey is used in the literature, but having in mind their suffering due to invasive diagnostic procedures and inappropriate and ineffective treatments we would like to introduce another term "diagnostic and therapeutic Golgotha".

\section{THE COMPLEX CHARACTER OF RARE RENAL DISEASES}

Rare renal diseases often progress to end stage kidney disease with the need for renal replacement therapy (dialysis and transplantation). Wuhl et al analyzed the data extracted from the ERA-EDTA registry on renal replacement therapy [7]. In a five year period $(01 / 01 / 2007-31 / 12 /$ 2011) 7194 patients started renal replacement therapy (10.6\% children). Congenital anomalies of the kidney and urinary tract, cystinosis, primary hyperoxaluria and medullary cystic kidneys were etiologies in $46 \%$ of children. However, no patients with Fabry disease were reported. RDs, mainly of genetic origin, were more prevalent in children than in adults $-57 . \%$ versus $11.9 \%$. With improved techniques of renal replacement therapy many children with rare inherited disease survive, but face many complications and affection of many systems and organs. Also their neurocognitive development may be seriously impaired disturbing their full social integration. Bardet Biedl syndrome, a cilliopathic disease, is an example of multisystem disorder requiring comprehensive diagnostic and management process [8]. The renal component of the disease is considered as major one, besides obesity, intellectual disability, cardiopathy, hypogonadism and retinal dystrophy. The nephrologist is involved in diagnosing the nephropathy, prevention of progression to ESRD and finally renal replacement therapy. Cardiologist and cardiac surgeon are involved in treatment of the congenital cardiopthy, ophtalmologist for retinal dystrophy, endocrinologist for hypogonadism, obesity and glucose intolerance and plastic surgeon for polydactyly. Dietician, psychologist, social worker and physiotherapist are also the important members of the team who takes care of these patients.

Therefore, rare renal diseases have strong impact on the affected persons, their families, health system and society. As already mentioned, the patient very often undergo diagnostic/treatment Odyssey/Golgotha with many invasive and painful procedures. Their parents have to devote their time to the care of the child with RD often neglecting their own career and finances. The health system is faced with great expenses for the diagnosis and the treatment with the need for engaging a team of various health professionals. In addition, orphan drugs for some rare disease may have astronomic prices.

\section{ORPHAN DRUGS}

The production of drugs for orphan disease is long and laborious process. An important strategy when developing drugs is to use small molecule drugs which can inhibit their targets. Unfortunately, majority of single gene mutations lead to loss of function which is more difficult from pharmaceutical aspect in order to create agonist/activators which can save the function of the altered protein [9]. The database of DrugBank contains a library of 1700 small molecules but only 423 are agonist/ activators [10]. The diseases with adult/late onsets are advantageous for the treatment since there is enough time from diagnosis to the beginning of the treatment. Although they are RDs, their cumulative frequency makes them visible for the society and for the health policy makers trough their cumulative financial effect. 


\section{GENETIC RARE RENAL DISEASES- CHRONOLOGY}

Autosomal dominant polycytic disease is an inherited, but not a rare disease. It was mapped for the first time in 1980. The genetic basis of the Alport syndrome was established in 1990, followed by nephrogenic diabetes insipidus, Liddle's syndrome, Dent's disease, Bartter's and Gitelman's syndromes, nephropathic cystinosis and others. Gene products are involved in the structure and function of various enzymes, receptors, channels, transporters resulting in abnormal kidney function and structure but also in variety of extra renal abnormalities affecting the bones, growth, hearing, sight, and neurocognitive development. The basic method for molecular analysis is Sanger sequencing, introduced by Frederik Sanger and colleagues in 1977 and which has remained a cornerstone in the next three decades. Even now, in the next generation era it is still used for small-scale projects, validation of Next-Gen results, and for obtaining especially long contiguous DNA sequence reads (> 500 nucletides). The disadvantages are highcost and long time of sequencing.

\section{NEXT-GENERATION SEQUENCING TECHNOLOGIES}

The twenty first century is the era of personalized genetic medicine. Due to the enormous progress in molecular genetic techniques many Mendelian diseases have been characterized on the genetic basis, giving a possibility for appropriate preventive and treatment interventions, genetic counseling and prenatal diagnosis [11]. Contemporary techniques of next-generation sequencing enabled testing of thousand genes in a timely and cost-effective manner. Genetic basis of the disease might be detected by testing the exome/genome of a single patient with well defined phenotype. The rationale strategy should be based on testing one or few genes for disease without genetic heterogenicity, panel of genes for diseases with great genetic heterogenicity, or whole exome/genome sequencing if the previous tests were negative. Herein we will present few illustrative examples from the literature which, without doubt, show the enormous clinical benefits of the next generation sequencing.
The first case is a 15 -month-old baby with perianal abscess and proctitis, colorectal fistula and the clinical picture of Crohn-like disease [12]. Many surgical interventions and biologic therapy with infliximab were unsuccessful. Due to to the whole exome sequencing (WES) it was established that the patient carried mutation in $\mathrm{x}$ linked inhibitor of the apoptosis which is an important gene in the proinflamatory response and bacterial sensitivity through the NOD signaling pathway. Based on this finding, an alogenic hematopoetic transplantation of progenitor cells was performed and the baby achieved long and stable remission.

The next example is of a baby with clinical features of Bartter syndrome and negative genetic tests who underwent WES and was found to have a homozygous missense mutation in SLC26A3 which led to correct diagnosis provided it is congenital chloridorrhea [13].

Due to WES we established a diagnosis of Dent 1 disease in two brothers with bilataral nephrocalcinosis, 28 years after initial presentation [14].

WES established a diagnosis of the first case of urofacial syndrome in Macedonia, without any previous clinical suspicion [15].

A sixteen year old girl with incidental finding of bilateral medullary nephrocalcinosis was found to have a mutation in CYP24A gene, an important finding for further management of this girl [14].

The benefits of the new molecular genetics techniques particularly in pediatrics and rare disease are clear. But one should be aware of few things - production of many variants which cannot be interpreted in the clinical context, variants of unknown significance, reporting of incidental findings and ethical aspects.

\section{RARE RENAL DISEASES IN MACEDONIA-CURRENT STATUS}

Unfortunately there is no coordinated action between health professionals, patients and health authorities in order to analyze the situation in the country and raise the awareness for RRD. Usually it is raised at the last stage, when these patients reach and stage renal disease with the need for dialysis and transplantation. Also there is no registry for RRD. The benefit of such register is significant since it will enable creation of health 
policies, providing adequate funds and improved care of these patients. The data collected within the registry will enable our scientists to analyze and exchange these data on international level. And finally the greatest benefit is for the patients - this will enable participation in the international trials. Macedonia is a country with low resources, particularly regarding supply with orphan drugs. Therefore, participants in trials which will result in effective treatments will have permanent supply of orphan drugs free of charge.

In our previous work on rare renal diseases we presented the contribution of the Macedonian health professionals to diagnosis and treatment of RRD [16]. It is still an enthusiastic work of several clinicians and scientist concentrated at the University Children's Hospital, Nephrology Clinic and Macedonian Academy of Science and Arts. A firm international collaboration was established with Boston Children's Hospital, Harvard Medical School (Prof. Hildebrandt's Laboratory) and Department of Nephrology-Columbia University. The research interest is focused on the genetics of congenital anomalies of the kidney and urinary tract (CAKUT), steroid resistant nephrotic syndrome, nephrolithiasis and nephrocalcinosis, cystic diseases and cilliopathies. This collaboration resulted in detection of new genes and new pathophysiological pathways, two of them published in New England Journal of Medicine [17, 18] and in other high impact Journals such as American Journal of Human Genetics, Journal of the American Society of Nephrology, Clinical Journal of American Society of Nephrology, Kidney International, Nephrology Dialysis and Transplantation. The novel genes detected in these laboratories with participation of patients from Macedonia are DSTYC, TBX18, NRIP1, SLC26A1, SLIT2, SRGAP1, ITGA8, TRAP1, FRAS1, FREM2 etc $[19,20,21,22,23,24,25]$.

Collaboration with the group from Mayo Clinic resulted in detection of the third gene for autosomal dominant polycystic kidney diseases GANAB (one among eight families comes from Macedonia) [26].

International collaboration is very important, since RRD are mainly genetic in origin, and the participation of our clinicians and scientists in the working groups is of utmost importance. European Society for Pediatric Nephrology has several working groups among which Group for Inherited Kidney Diseases and CAKUT group (http://espn-online.org/espn_working_groups.php). These groups support the research in the respective field, organize and design multicentre clinical studies and publish articles. EDTA-ERA also has Working Group on Inherited Kidney Disorders (WGIKD; http://www.era-edta.org/wgikd/ERA-DTA_working_group_on_Inherited_kidney_disorders.htm). Also European Network for the Study of Orphan Nephropathies (EUNEFRON; http://www.eunefron.org).

International collaboration is very important for diagnostic of RRD. The diagnostic pathway is sometimes very complex, requiring extensive clinical, biochemical, metabolic and genetic investigations. This can be done with sophisticated equipment and well trained staff. Diagnostic facilities in Macedonia, particularly for metabolic studies, are very limited. Therefore the Ministry of Health and the health fund should enable such testing to be done in certified laboratories abroad with fully paid costs. The earlier diagnosis and the earlier treatment are chance to prevent or stop progression to ESRD. Diagnosis and treatment of RRD nowadays is based firmly on molecular genetics diagnosis. Although next generation sequencing technology is available in Macedonia (laboratory at the Macedonian Academy of Science and Arts and Pharmaceutical Faculty) their use is very limited, mainly for scientific projects. Yet "routine" next generation technology is not available to clinicians since it is not covered by the Health Insurance Fund.

In order to attract the attention of clinicians, scientists, geneticists and other health related professionals The Macedonian Academy of Science and Arts has organized annual Conferences on Rare Disease in Southeast Europe since 2012 [27, $28,29,30]$. Topics from the RRD were frequently included in the scientific program with eminent lecturers from Macedonia, neighboring countries and Europe. The lectures and topics were related to Renal Hypouricemia, CAKUT, Idiopathic infantile hypercalcemia, Steroid resistant nephrotic syndrome, atypical HUS etc.

\section{FUTURE DIRECTIONS AND CONCLUSION}

$\mathrm{RRD}$ represent a great challenge for the health professionals, health authorities, families and society in general, due to their complex character and the need for comprehensive treatment. 
Further efforts should be made to improve the diagnosis, primarily through education during the medical studies and later during specializations in pediatrics, internal medicine, neurology and other specialties. The best advocates for the patients' right are their organizations. In Macedonia there is an Alliance of Patients with Rare Disease, and within this group an organization for patients with RRD should be established. The Macedonian health professionals have an adequate knowledge and equipment for diagnostics of RRD, unfortunately the lack of finances is a great obstacle for early and appropriate diagnosis. Participation in international registries, studies and trials should be encouraged; this will result in benefit for all: the patients, their families, health professionals and the society.

\section{REFERENCES}

1. Devuyst O, Knoers NV, Remuzzi G, Schaefer F; Board of the Working Group for Inherited Kidney Diseases of the European Renal Association and European Dialysis and Transplant Association. Rare inherited kidney diseases: challenges, opportunities, and perspectives. Lancet. 2014;383(9931):1844-59.

2. Soliman NA. Orphan kidney diseases. Nephron Clin Pract. 2012;120(4):c194-9.

3. Popovska-Jankovic K1, Tasic V, Bogdanovic R, Miljkovic P, Golubovic E, Soylu A, Saraga M, Pavicevic S, Baskin E, Akil I, Gregoric A, Lilova M, Topaloglu R, Sukarova Stefanovska E, Plaseska-Karanfilska D. Molecular characterization of cystinuria in south-eastern European countries. Urolithiasis. 2013;41(1):21-30.

4. Tasic V, Hynes AM, Kitamura K, Cheong HI, Lozanovski VJ, Gucev Z, Jutabha P, Anzai N, Sayer JA. Clinical and functional characterization of URAT1 variants. PLoS One. 2011;6(12):e28641.

5. Bertholet-Thomas A, Berthiller J, Tasic V, Kassai B, Otukesh H, Greco M, Ehrich J, de Paula Bernardes R, Deschênes G, Hulton SA, Fischbach M, Soulami K, Saeed B, Valavi E, Cobenas CJ, Hacihamdioglu B, Weiler G, Cochat P, Bacchetta J. Worldwide view of nephropathic cystinosis: results from a survey from 30 countries. BMC Nephrol. 2017;18(1):210.

6. Bertholet-Thomas A, Bacchetta J, Tasic V, Cochat P. Nephropathic cystinosis--a gap between developing and developed nations. N Engl J Med. 2014;370(14):1366-7
7. Wühl E, van Stralen KJ, Wanner C, Ariceta G, Heaf JG, Bjerre AK, Palsson R, Duneau G, Hoitsma AJ, Ravani P, Schaefer F, Jager KJ. Renal replacement therapy for rare diseases affecting the kidney: an analysis of the ERA-EDTA Registry.Nephrol Dial Transplant. 2014 Sep;29 Suppl 4:iv1-8

8. Ristoska Bojkovska N, Spahiu L, Janchevska A, Gucev ZS, Tasic V. Renal dysplasia in Bardet-Biedl syndrome. Pril (Makedon Akad Nauk Umet Odd Med Nauki). 2015;36(1):211-5.

9. Chen B, Altman RB. Opportunities for developing therapies for rare genetic diseases: focus on gainof-function and allostery. Orphanet J Rare Dis. 2017;12(1):61.

10. Law V, Knox C, Djoumbou Y, Jewison T, Guo AC, Liu Y, Maciejewski A, Arndt D, Wilson M, Neveu $\mathrm{V}$, et al. DrugBank 4.0: shedding new light on drug metabolism. Nucleic Acids Res. 2014;42(Database issue):D1091-1097

11. Hildebrandt F. Genetic kidney diseases. Lancet. 2010;375(9722):1287-95.

12. Worthey EA, Mayer AN, Syverson GD, Helbling D, Bonacci BB, Decker B, Serpe JM, Dasu T, Tschannen MR, Veith RL, Basehore MJ, Broeckel U, Tomita-Mitchell A, Arca MJ, Casper JT, Margolis DA, Bick DP, Hessner MJ, Routes JM, Verbsky JW, Jacob HJ, Dimmock DP. Making a definitive diagnosis: successful clinical application of whole exome sequencing in a child with intractable inflammatory bowel disease. Genet Med. 2011;13(3):255-62.

13. Choi M, Scholl UI, Ji W, Liu T, Tikhonova IR, Zumbo P, Nayir A, Bakkaloğlu A, Ozen S, Sanjad S, Nelson-Williams C, Farhi A, Mane S, Lifton RP. Genetic diagnosis by whole exome capture and massively parallel DNA sequencing. Proc Natl Acad Sci U S A. 2009;106(45):19096-101.

14. Halbritter J, Baum M, Hynes AM, Rice SJ, Thwaites DT, Gucev ZS, Fisher B, Spaneas L, Porath JD, Braun DA, Wassner AJ, Nelson CP, Tasic V, Sayer JA, Hildebrandt F. Fourteen monogenic genes account for $15 \%$ of nephrolithiasis/nephrocalcinosis. J Am Soc Nephrol. 2015;26(3):543-51

15. Vivante A, Hwang DY, Kohl S, Chen J, Shril S, Schulz J, van der Ven A, Daouk G, Soliman NA, Kumar AS, Senguttuvan P, Kehinde EO, Tasic V, Hildebrandt F. Exome Sequencing Discerns Syndromes in Patients from Consanguineous Families with Congenital Anomalies of the Kidneys and Urinary Tract. J Am Soc Nephrol. 2017;28(1):69-75

16. Tasic V, Lozanovski VJ, Danilovski D, Laban N, Pop-Jordanova N, Polenakovic M, Gucev ZS. Rare diseases with renal involvement in the Republic of Macedonia. Prilozi. 2011;32(1):55-67.

17. Sanna-Cherchi S, Sampogna RV, Papeta N, Burgess KE, Nees SN, Perry BJ, Choi M, Bodria M, 
Liu Y, Weng PL, Lozanovski VJ, Verbitsky M, Lugani F, Sterken R, Paragas N, Caridi G, Carrea A, Dagnino M, Materna-Kiryluk A, Santamaria G, Murtas C, Ristoska-Bojkovska N, Izzi C, Kacak N, Bianco B, Giberti S, Gigante M, Piaggio G, Gesualdo L, Kosuljandic Vukic D, Vukojevic K, Saraga-Babic M, Saraga M, Gucev Z, Allegri L, Latos-Bielenska A, Casu D, State M, Scolari F, Ravazzolo R, Kiryluk K, Al-Awqati Q, D'Agati VD, Drummond IA, Tasic V, Lifton RP, Ghiggeri GM, Gharavi AG. Mutations in DSTYK and dominant urinary tract malformations. N Engl J Med. 2013;369(7):621-9

18. Lopez-Rivera E, Liu YP, Verbitsky M, Anderson BR, Capone VP, Otto EA, Yan Z, Mitrotti A, Martino J, Steers NJ, Fasel DA, Vukojevic K, Deng R, Racedo SE, Liu Q, Werth M, Westland R, Vivante A, Makar GS, Bodria M, Sampson MG, Gillies CE, Vega-Warner V, Maiorana M, Petrey DS, Honig B, Lozanovski VJ, Salomon R, Heidet L, Carpentier W, Gaillard D, Carrea A, Gesualdo L, Cusi D, Izzi C, Scolari F, van Wijk JA, Arapovic A, Saraga-Babic M, Saraga M, Kunac N, Samii A, McDonald-McGinn DM, Crowley TB, Zackai EH, Drozdz D, Miklaszewska M, Tkaczyk M, Sikora P, Szczepanska M, Mizerska-Wasiak M, Krzemien G, Szmigielska A, Zaniew M, Darlow JM, Puri P, Barton D, Casolari E, Furth SL, Warady BA, Gucev Z, Hakonarson H, Flogelova $\mathrm{H}$, Tasic V, Latos-Bielenska A, Materna-Kiryluk A, Allegri L, Wong CS, Drummond IA, D'Agati V, Imamoto A, Barasch JM, Hildebrandt F, Kiryluk $\mathrm{K}$, Lifton RP, Morrow BE, Jeanpierre C, Papaioannou VE, Ghiggeri GM, Gharavi AG, Katsanis N, Sanna-Cherchi S. Genetic Drivers of Kidney Defects in the DiGeorge Syndrome. N Engl J Med. 2017;376(8):742-754

19. Vivante A, Mann N, Yonath H, Weiss AC, Getwan M, Kaminski MM, Bohnenpoll T, Teyssier C, Chen J, Shril S, van der Ven AT, Ityel H, Schmidt JM, Widmeier E, Bauer SB, Sanna-Cherchi S, Gharavi AG, Lu W, Magen D, Shukrun R, Lifton RP, Tasic V, Stanescu HC, Cavaillès V, Kleta R, Anikster Y, Dekel B, Kispert A, Lienkamp SS, Hildebrandt F. A Dominant Mutation in Nuclear Receptor Interacting Protein 1 Causes Urinary Tract Malformations via Dysregulation of Retinoic Acid Signaling. J Am Soc Nephrol. 2017 Apr 5. pii: ASN.2016060694

20. Gee HY, Jun I, Braun DA, Lawson JA, Halbritter J, Shril S, Nelson CP, Tan W, Stein D, Wassner AJ, Ferguson MA, Gucev Z, Sayer JA, Milosevic D, Baum M, Tasic V, Lee MG, Hildebrandt F. Mutations in SLC26A1 Cause Nephrolithiasis. Am J Hum Genet. 2016 ;98(6):1228-34.

21. Vivante A, Kleppa MJ, Schulz J, Kohl S, Sharma A, Chen J, Shril S, Hwang DY, Weiss AC,
Kaminski MM, Shukrun R, Kemper MJ, Lehnhardt A, Beetz R, Sanna-Cherchi S, Verbitsky M, Gharavi AG, Stuart HM, Feather SA, Goodship JA, Goodship TH, Woolf AS, Westra SJ, Doody DP, Bauer SB, Lee RS, Adam RM, Lu W, Reutter HM, Kehinde EO, Mancini EJ, Lifton RP, Tasic V, Lienkamp SS, Jüppner H, Kispert A, Hildebrandt F. Mutations in TBX18 Cause Dominant Urinary Tract Malformations via Transcriptional Dysregulation of Ureter Development. Am J Hum Genet. 2015;97(2):291-301

22. Hwang DY, Kohl S, Fan X, Vivante A, Chan S, Dworschak GC, Schulz J, van Eerde AM, Hilger AC, Gee HY, Pennimpede T, Herrmann BG, van de Hoek G, Renkema KY, Schell C, Huber TB, Reutter HM, Soliman NA, Stajic N, Bogdanovic R, Kehinde EO, Lifton RP, Tasic V, Lu W, Hildebrandt F. Mutations of the SLIT2-ROBO2 pathway genes SLIT2 and SRGAP1 confer risk for congenital anomalies of the kidney and urinary tract. Hum Genet. 2015;134(8):905-16

23. Kohl S, Hwang DY, Dworschak GC, Hilger AC, Saisawat P, Vivante A, Stajic N, Bogdanovic R, Reutter HM, Kehinde EO, Tasic V, Hildebrandt F. Mild recessive mutations in six Fraser syndrome-related genes cause isolated congenital anomalies of the kidney and urinary tract. J Am Soc Nephrol. 2014;25(9):1917-22

24. Saisawat P, Kohl S, Hilger AC, Hwang DY, Yung Gee H, Dworschak GC, Tasic V, Pennimpede T, Natarajan S, Sperry E, Matassa DS, Stajić N, Bogdanovic R, de Blaauw I, Marcelis CL, Wijers CH, Bartels E, Schmiedeke E, Schmidt D, Märzheuser S, Grasshoff-Derr S, Holland-Cunz S, Ludwig M, Nöthen MM, Draaken M, Brosens E, Heij H, Tibboel D, Herrmann BG, Solomon BD, de Klein A, van Rooij IA, Esposito F, Reutter HM, Hildebrandt $\mathrm{F}$. Whole-exome resequencing reveals recessive mutations in TRAP1 in individuals with CAKUT and VACTERL association.Kidney Int. 2014;85(6):1310-7

25. Saisawat P1, Tasic V, Vega-Warner V, Kehinde EO, Günther B, Airik R, Innis JW, Hoskins BE, Hoefele J, Otto EA, Hildebrandt F. Identification of two novel CAKUT-causing genes by massively parallel exon resequencing of candidate genes in patients with unilateral renal agenesis. Kidney Int. 2012;81(2):196-200.

26. Porath B, Gainullin VG, Cornec-Le Gall E, Dillinger EK, Heyer CM, Hopp K, Edwards ME, Madsen CD, Mauritz SR, Banks CJ, Baheti S, Reddy B, Herrero JI, Bañales JM, Hogan MC, Tasic V, Watnick TJ, Chapman AB, Vigneau C, Lavainne F, Audrézet MP, Ferec C, Le Meur Y, Torres VE; Genkyst Study Group, HALT Progression of Polycystic Kidney Disease Group; Consortium for Radiologic Imaging Studies of 
Polycystic Kidney Disease, Harris PC. Mutations in GANAB, Encoding the Glucosidase II $\alpha$ Subunit, Cause Autosomal-Dominant Polycystic Kidney and Liver Disease.Am J Hum Genet. 2016;98(6):1193-207.

27. Gucev Z, Tasic V, Polenakovic M. 5th Rare Disease South Eastern Europe (SEE) Meeting, Skopje, Macedonia (November 15th, 2016). Pril (Makedon Akad Nauk Umet Odd Med Nauki). 2017 Mar 1;38(1):119-123

28. Gucev Z, Tasic V, Polenakovic M. 4th Rare Disease South Eastern Europe (See) Meeting
Skopje, Macedonia (November 14th, 2015).Pril (Makedon Akad Nauk Umet Odd Med Nauki). 2015;36(3):151-6.

29. Polenakovic M, Gucev Z, Tasic V. Where are we now in the investigation of rare diseases in the Republic of Macedonia? Pril (Makedon Akad Nauk Umet Odd Med Nauki). 2014;35(1):85-6. Review.

30. Gucev Z, Tasic V, Polenakovic M. The many faces of rare diseases (RD): meeting report on Rare Disease in South-Eastern Europe, 15-16 November 2013, Skopje, Republic of Macedonia. Pediatr Endocrinol Rev. 2014 Mar;11(3):337-8.

\title{
Резиме
}

\section{РЕТКИ БУБРЕЖНИ ЗАБОЛУВАЊА ВО МАКЕДОНИЈА - НОВИ СОЗНАНИЈА}

\section{Велибор Тасиќ ${ }^{1}$, Зоран Гучев ${ }^{1}$, Момир Поленаковиќ ${ }^{2}$}

\author{
${ }^{1}$ Универзитетска детска болница, Медицински факултет, Скопје, Република Македонија \\ ${ }^{2}$ Македонија академија на науките и уметностите, Скопје, Република Македонија
}

Ретките бубрежни заболувања (RRD) се важна категорија на ретки болести (RD), бидејќ тие можат да им направат голема штета на пациентите, на семејствата и на општеството. Пациентот може со години, дури и со децении да биде подложен на бројни испитувања, вклучувајќ и инвазивни процедури, а сепак, да нема дефинитивна и прецизна дијагноза и поради тоа да нема можност за соодветен третман. Големиот напредок во молекуларните генетски техники карактеризираше многу Менделови болести на молекуларно ниво. Ова овозможи соодветни интервенции за превенција и за третман, генетско советување и пренатална дијагноза. Овде го сумираме моменталниот статус на RRD во Македонија. Истражувачкиот интерес на македонските лекари и научници е фокусиран на генетиката на вродени аномалии на бубрежниот и на уринарниот тракт (CAKUT), нефротичен синдром отпорен на стероиди, нефролитијаза и нефрокалциноза, цистични болести и цилиопатии, во соработки со еминентни лаборатории во САД и во Европа. Оваа соработка резултираше со откривање на нови гени и патофизиолошки патишта објавени во The New England Journal of Medicine и во други списанија со висок ефект. Македонските здравствени работници имаат знаење и опрема за дијагностицирање на RRD. За жал, недостигот на финансии е голема пречка за рана и соодветна дијагностика. Треба да се поттикне учество во меѓународните регистри, студии и испитувања. Ова ќе резултира со значителна корист за пациентите, здравствените работници и за науката.

Клучни зборови: ретки бубрежни заболувања, генетски, Македонија 